\title{
Elastase of U-937 Monocytelike Cells
}

\author{
COMPARISONS WITH ELASTASES DERIVED FROM HUMAN MONOCYTES
}

\author{
AND NEUTROPHILS AND MURINE MACROPHAGELIKE CELLS
}

\author{
Robert M. Senior, Edward J. Campbell, Jill A. Landis, Fraya R. Cox, \\ Charles KuhN, and Hillel S. Koren, Departments of Medicine and \\ Pathology, Washington University School of Medicine and Pulmonary \\ Division, Department of Medicine, The Jewish Hospital of St. Louis, \\ St. Louis, Missouri 63110; Division of Immunology, Department of Medicine, \\ Duke University Medical Center, Durham, North Carolina 27710
}

\begin{abstract}
A B S TRACT As an approach to facilitating the understanding of proteinases associated with monocytes we have studied U-937 monocytelike cells. Elastase activity was identified in U-937 cell extracts and compared to monocyte elastase activity, neutrophil elastase, and the elastase activity from a continuous line of murine macrophagelike cells (P388D1). Serine proteinase activity which solubilized ${ }^{14} \mathrm{C}$-labeled elastin accounted for $>90 \%$ of the neutral proteinase activity of both U-937 cells and monocyte extracts. U-937 cell and monocyte elastase activities were similar catalytically, resembling neutrophil elastase. U-937 cells and monocytes showed other similarities: $(a)$ both had activities reacting with $\left[{ }^{3} \mathrm{H}\right]$ diisopropylfluorophosphate that migrated in sodium dodecyl sulfate (SDS) polyacrylamide gels at $\sim 30,000$ and 60,000 daltons and (b) both contained material that cross-reacted with antiserum raised to neutrophil elastase. Preliminary characterization of U-937 cell elastase activity by affinity chromatography and ion-exchange chromatography suggested the presence of at least two distinct elastases. Minimal elastase activity was found in U-937 cell-conditioned medium, indicating that the activity is not spontaneously released by the cells. In contrast to the elastase activity associated with U-937 cells and monocytes, the elastase activity associated with P388D1
\end{abstract}

This work was presented in preliminary form at the Annual Meeting of the American Society for Clinical Investigation, 12 May 1980, and published in abstract form in 1980 (Clin. Res. 28: 531a.).

Address correspondence to Dr. Robert M. Senior, Department of Medicine, The Jewish Hospital of St. Louis, Mo. 63110.

Received for publication 29 December 1980 and in revised form 25 September 1981. cells was a metalloproteinase and was found principally in the culture medium. These results indicate (a) U-937 cells will be useful for further investigation of proteinases associated with normal monocytes; $(b)$ monocytes and U-937 cells contain material with catalytic and immunologic similarities to neutrophil elastase; $(c)$ monocyte elastase activity differs from elastase activity secreted by murine macrophages and murine macrophagelike cells of the P388D1 line.

\section{INTRODUCTION}

Interest in elastases derived from inflammatory cells has been stimulated by recognition that these enzymes may be important in connective tissue injury, notably in rheumatoid arthritis and pulmonary emphysema (1). Neutrophil elastase (HLE) ${ }^{1}$ has been shown to produce marked connective tissue destruction in experimental models, and is capable of producing pulmonary emphysema when instilled intratracheally into experimental animals $(2,3)$. Macrophages have been identified as another source of elastase activity that may have a role in connective tissue destruction (4-6). Macrophage elastase activity, studied most thoroughly

\footnotetext{
${ }^{1}$ Abbreviations used in this paper: Boc-Ala-SNp, N-tbutoxycarbonyl-L-alanine-p-nitrothiophenyl ester; CMK, methoxysuccinyl - alanyl - alanyl - prolyl - valyl - chloromethyl ketone; DFP, diisopropyl fluorophosphate; ELISA, enzymelinked immunoabsorbent assay; HLE, human neutrophil elastase; MSAPN, methoxy-succinyl-alanyl-alanyl-prolyl-valyl-p-nitroanilide; PBS, phosphate-buffered saline; PMSF, phenylmethylsulfonyl fluoride; SBTI, soybean trypsin inhibitor; SLAPN, succinyl-L-alanyl-L-alanyl-L-alanine-p-nitroanilide.
} 
using murine macrophages, differs from neutrophil elastase in its catalytic properties and its susceptibility to proteinase inhibitors (7).

Recent information suggests that monocytes have elastolytic activity that shares catalytic features with neutrophil elastase rather than with murine macrophage elastase $(8,9)$. These data are noteworthy for at least two reasons: $(a)$ they are further evidence for developmental alterations in monocytes during differentiation into macrophages (10-12), and (b) they indicate another source of elastolytic activity that could be active whenever there is insufficient alpha1-proteinase inhibitor or when alpha-1-proteinase inhibitor has been oxidatively inactivated (13). Thus, monocyte-derived elastase activity might be important in the disease processes in which neutrophil elastase has been implicated.

Studies with monocytes are hampered by the limitations upon obtaining large numbers of the cells free from contamination with other cell types. Moreover, the finding that monocytes and macrophages have cell surface receptors for neutrophil elastase either free or in complex with alpha-2-macroglobulin raises the additional problem that some of the elastase activity associated with monocytes may be due to internalized enzyme (14).

In an effort to further characterize human mononuclear phagocyte elastase we have turned to a continuous line of monocytelike cells, designated U-937. This approach was suggested by $(a)$ Werb et al. (15), who observed that a continuous line of murine macrophagelike cells, P388D1, release an elastase activity that appears to have the same catalytic properties as elastase activity obtained from normal murine macrophages and $(b)$ the recent interest in lines of monocyte and macrophagelike cells which, as noted by Ralph (16), offer advantages that the cells are not contaminated by other cell types, the cells divide rapidly, and the different cell lines display developmental characteristics representative of normal macrophages in varying stages of maturity.

The U-937 cell line of human origin has proven valuable for studying characteristics of immature human macrophages. U-937 cells are phagocytic and have positive nonspecific esterase staining (17). They spontaneously release lysozyme and endogenous pyrogen $(18,19)$. Upon stimulation with lymphokines U-937 cells acquire cell surface receptors for chemotactic factors, show directional responses and lysosomal enzyme release in response to chemotactants, demonstrate induction of antibody-dependent cytotoxicity, and have improved microbicidal activity against intracellular pathogens (20-22).

In this report, we describe the elastase activity present in extracts of U-937 cells, and compare U-937 cell elastase with elastase activity from monocytes, neutrophils, and P388Dl cells.

\section{METHODS}

Cell culture. U-937 cells were kept in suspension cultures in RPMI 1640 medium (Basic Cancer Research Center, Washington University School of Medicine, St. Louis, Mo.), supplemented with $2.5 \%$ fetal bovine serum and $2.5 \%$ bovine serum (KC Biological, Inc., Lenexa, Kans.), 2 mM glutamine, $1 \%$ nonessential amino acids, $2 \mathrm{mM}$ sodium pyruvate, and $25 \mu \mathrm{g} / \mathrm{ml}$ of gentamicin (Schering, Chicago, Ill.). When the cells reached a density of $10^{6}$ cells $/ \mathrm{ml}$ they were subcultured at $3 \times 10^{5}$ cells $/ \mathrm{ml}$. P388Dl cells obtained from the Salk Institute, San Diego, Calif. were cultured in Dulbecco's modified Eagle's medium supplemented with $10 \%$ fetal calf serum and nonessential amino acids. Both cells lines were cultured in $5 \% \mathrm{CO}_{2}-95 \%$ air at $37^{\circ} \mathrm{C}$.

Recovery of neutrophils and monocytes. To compare cell-line elastases with normal human leukocyte elastases, venous blood collected from healthy volunteers was separated into neutrophil and mononuclear cell fractions by centrifugation through Ficoll-Hypaque (23). The mononuclear cell fraction was subjected to elutriation centrifugation to obtain a purified population of monocytes (24). The monocyte populations were $>95 \%$ pure as judged by microscopic examination of Wright-stained cytocentrifuge preparations (Cytospin, Shandon Instruments, Sewickley, Pa.).

Preparation of cell extracts and cell conditioned medium. U-937 cells, monocytes, and neutrophils were disrupted by three cycles of freeze-thawing with methanol-dry ice, followed by 30-120 s of sonication (Sonic Dismembrator, model 300, Fisher Scientific, Co. Pittsburgh, Pa.) with 230 $\mathrm{W}$ at $4^{\circ} \mathrm{C}$. P388D 1 cells were washed twice with serumless medium and removed from the culture flask by scraping with a rubber policeman and then disrupted as described above. The mixtures of disrupted cells were spun at 14,000 $\mathrm{g}$ for $20 \mathrm{~min}$ at $4^{\circ} \mathrm{C}$ and the supernatant fluid was retained at $-70^{\circ} \mathrm{C}$ until assayed. The protein concentrations of the cell extracts were determined spectrophotometrically (Beckman DU8, Beckman Instruments, Inc., Fullerton, Calif.) (25) and related to the number of cells as counted on a hemocytometer.

To obtain cell conditioned medium for study of released elastase activity, U-937 and P388Dl cells were washed twice with serumless medium and then cultured for $24 \mathrm{~h}$ in serumless medium or serum-free medium supplemented with $0.2 \%$ lactalbumin hydrolysate (Gibco Laboratories, Grand Island Biological Co., Grand Island, N. Y.). After the 24-h culture period the medium was removed and the cells were checked for viability by trypan blue exclusion and release of lactate dehydrogenase and lysozyme activities into the medium. The cells were then resuspended in a volume of phosphate-buffered saline, (PBS; 0.050 M phosphate, $0.150 \mathrm{M}$ $\mathrm{NaCl}, \mathrm{pH} 7.4$ ), equal to the volume of harvested medium. The cell extracts and the cell-conditioned medium could thus be assayed at comparable dilutions.

Enzyme activities. Elastase activity was measured using ${ }^{14} \mathrm{C}$-labeled elastin, $300-800 \mathrm{cpm} / \mu \mathrm{g}$, and expressed as micrograms of elastin solubilized per $24 \mathrm{~h}$ at $37^{\circ} \mathrm{C}$ (26). HLE, purified from sputum, was used as a standard in every experiment (27). The HLE standard solubilized $0.8 \mu \mathrm{g}$ of ${ }^{14} \mathrm{C}$ labeled elastin/ng in $24 \mathrm{~h}$ at $37^{\circ} \mathrm{C}$ in PBS. The assays of $\mathrm{U}$ 937, monocyte, and neutrophil elastases were performed in PBS. Assays of P388D1 elastase activity were performed either in PBS or in $0.05 \mathrm{M}$ Tris- $\mathrm{HCl}, \mathrm{pH} \mathrm{8.0,} \mathrm{containing} 0.05 \mathrm{M}$ $\mathrm{CaCl}_{2}$. Elastaselike activity against synthetic substrates was 
determined using succinyl-L-alanyl-L-alanyl-L-alanine- $p$-nitroanilide, (SLAPN; BACHEM, Inc., Torrance, Calif.) and methoxy-succinyl-alanyl-alanyl-prolyl-valyl- $p$-nitroanilide (MSAPN) obtained from Dr. James C. Powers, Georgia Institute of Technology, Atlanta, Ga. $(28,29)$. Lactate dehydrogenase and lysozyme activities were measured by standard procedures $(30,31)$. Nonspecific neutral proteinase activity was determined with ${ }^{125} \mathrm{I}$-labeled, native, plasmaderived fibronectin (a gift from Dr. John A. McDonald, Washington University Medical Center, St. Louis, Mo.) in a solid-phase assay similar to the procedure described by Varani et al. (32). The assay conditions, $3 \mathrm{~h}$ of incubation at $37^{\circ} \mathrm{C}$ at $\mathrm{pH} 7.5$, provided a linear response between the quantity of purified proteolytic enzyme (trypsin, chymotrypsin, porcine pancreatic elastase, and HLE), or cell extracts, and the release of radiolabeled peptides, with a workable range of $2.5-20 \mathrm{ng}$ for trypsin and comparable sensitivity for the other enzymes tested.

$p H$ profile. The influence of $\mathrm{pH}$ upon elastase activity was examined by incubating $50 \mu \mathrm{l}$ of the test material with $150 \mu$ l of buffer for $24 \mathrm{~h}$ in the presence of ${ }^{14} \mathrm{C}$-labeled elastin, as in the standard elastase assay. The buffers, $0.4 \mathrm{M}$, were sodium acetate, $\mathrm{pH} 5.5$; morpholinopropanesulfonic acid,

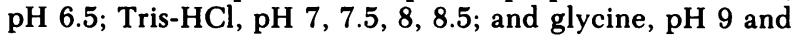
10. Buffer $\mathrm{pH}$ was confirmed at the conclusion of each assay.

Inhibition profile. To examine the effects of proteinase inhibitors on elastase activity, test materials were assayed for residual elastase activity after incubation with the inhibitor for $\mathrm{lh}$ at room temperature. With inhibitors requiring organic solvents for solubilization, the inhibitory effect of the solvent alone was determined. The following materials were tested for elastase inhibitory capacity: human alpha-1-proteinase inhibitor (from Dr. John A. Pierce, Washington University School of Medicine, St. Louis, Mo.), methoxy-succinyl-alanyl-alanyl-prolyl-valyl-chloromethylketone (CMK; obtained from Dr. James C. Powers), soybean trypsin inhibitor (SBTI), leupeptin, EDTA with the pH adjusted to 7.4 using $1 \mathrm{~N} \mathrm{NaOH}$, and phenylmethylsulfonyl fluoride (PMSF). Unless otherwise specified, the reagents were from Sigma Chemical Co., St. Louis, Mo. CMK was dissolved in methanol and PMSF was dissolved in dry dimethylformamide. The other inhibitors were dissolved in PBS.

Effects of $\mathrm{NaCl}$ and $\mathrm{CaCl}_{2}$ upon elastase activity. U-937 cell extracts and P388D1 cell-conditioned medium were dialyzed for $24 \mathrm{~h}$ at $4^{\circ} \mathrm{C}$ against $0.05 \mathrm{M}$ Tris- $\mathrm{HCl}, \mathrm{pH} 8.0$. Fixed amounts of the retentate were assayed for elastase activity in $0.05 \mathrm{M}$ Tris- $\mathrm{HCl}, \mathrm{pH} 8.0$, containing varying final concentrations of $\mathrm{NaCl}(0.05-0.40 \mathrm{M})$, and/or $\mathrm{CaCl}_{2}(0.0001-$ $0.010 \mathrm{M})$.

Nonelastolytic neutral proteinase activity in U-937 cell extract. To determine the proportion of nonelastolytic neutral proteinase activity in U-937 and monocyte cell extracts, the cell extracts were tested for proteinase activity against ${ }^{125} \mathrm{I}$-labeled fibronectin $(1,000-2,000 \mathrm{cpm} / \mu \mathrm{g})$ before and after incubation with the elastase inhibitor methoxy-succinyl-alanyl-alanyl-prolyl-valyl-chloromethyl ketone (CMK). Cell extract was incubated for $1 \mathrm{~h}$ at room temperature with a concentration of CMK $(300 \mu \mathrm{M})$, which completely inhibited the extract's activity against ${ }^{14} \mathrm{C}$-labeled elastin. The cell extract-CMK mixture was then diluted for assay for proteolytic activity against fibronectin. Identical dilutions of the cell extracts without CMK solubilized an amount of ${ }^{125} \mathrm{I}$-labeled fibronectin that was on the linear portion of the standard curve of the proteinase assay.

\section{Chromatographic studies}

Affinity chromatography. Trasylol (Bayer AG, Wuppertal, West Germany) was coupled to Sepharose (27). U-937 cell extract $(6.5 \mathrm{ml})$, or $100 \mu \mathrm{g}$ HLE, adjusted to $\mathrm{pH} 8$ in PBS, was applied to a column, $1.5 \times 8 \mathrm{~cm}$, and eluted with $0.05 \mathrm{M}$ Tris, $1.0 \mathrm{M} \mathrm{NaCl}, \mathrm{pH} 8$ at $4^{\circ} \mathrm{C}$. When the absorbance at $280 \mathrm{~nm}$ returned to the base line, the eluting buffer was changed to $0.05 \mathrm{M}$ sodium acetate, $0.4 \mathrm{M} \mathrm{NaCl}, \mathrm{pH}$. The fractions, $3 \mathrm{ml}$, were measured for absorbance at $280 \mathrm{~nm}$ and assayed for elastase activity against ${ }^{14} \mathrm{C}$-labeled elastin.

Ion-exchange chromatography. A CM-Sephadex (Sigma Chemical Co.) column $(1.6 \times 10-\mathrm{cm})$ was equilibrated with $0.05 \mathrm{M}$ sodium phosphate, $\mathrm{pH} 6.6$, and $3 \mathrm{ml}$ of $\mathrm{U}-937$ cell extract or $100 \mu \mathrm{g}$ HLE was then applied to the column at $4^{\circ} \mathrm{C}$ and eluted into $3-\mathrm{ml}$ fractions at a flow rate of $20 \mathrm{ml} /$ h. After the absorbance of the eluate returned to the baseline, the column was eluted with a linear salt gradient, 0-1.0 M $\mathrm{NaCl}$. The absorbance at $280 \mathrm{~nm}$, conductivity, and elastase activity of the eluate were measured.

Radiolabeling with $\left[{ }^{3} \mathrm{H}\right]$ diisopropylfluorophosphate (DFP) followed by polyacrylamide gel electrophoresis. Extracts of U-937 cells, and pools of the elastase containing peaks recovered by eluting the cell extracts from Trasylol-Sepharose, were labeled with $\left[{ }^{3} \mathrm{H}\right] \mathrm{DFP}$ by the procedure of Danø and Reich (33). Briefly, $\left[{ }^{3} \mathrm{H}\right] \mathrm{DFP}(6.5 \mathrm{Ci} / \mathrm{mM}$, Amersham Corp., Arlington Heights, Ill.), dissolved in propylene glycol, was incubated for $6 \mathrm{~h}$ at room temperature with samples of cell extract in a volume of $600 \mu \mathrm{l}$. The samples were then brought to $1.5 \mathrm{ml}$ with water, dialyzed for $48 \mathrm{~h}$ against cold water, evaporated, and reconstituted to $300 \mu \mathrm{l}$ with water. The small amount of precipitate that formed was removed by centrifugation for $30 \mathrm{~s}$ (Microfuge B, Beckman Instruments, Inc., Palo Alto, Calif.) and then the samples were studied by sodium dodecyl sulfate (SDS)-polyacrylamide gel electrophoresis (34). $60-\mu \mathrm{l}$ aliquots were boiled for $3 \mathrm{~min}$ in $2 \%$ SDS containing $0.77 \%$ dithiothreitol. Samples were then electrophoresed using discontinuous slab-gel electrophoresis with a $3 \%$ polyacrylamide stacking gel and a $10 \%$ polyacrylamide resolving gel. All gels and buffers contained $0.1 \%$ SDS. A mixture of ${ }^{14} \mathrm{C}$-labeled standards (New England Nuclear, Boston, Mass.) was run reduced in each gel. The radiolabeled products were located by autofluorography using Enhance (New England Nuclear, Boston, MA) and Kodak RP X-omat film (Eastman Kodak Co., Rochester, N. Y.) (35).

\section{Immunological studies}

Antiserum. Antiserum to HLE was raised in 8-wk-old BALB/c mice (Jackson Laboratories, Bar Harbor, Maine) by intraperitoneal injections of $100 \mu \mathrm{g} \mathrm{HLE}(1 \mathrm{mg} / \mathrm{ml}, \mathrm{wt} / \mathrm{vol})$ at 2-wk intervals. For the first immunization HLE was mixed $1: 1, \mathrm{vol} / \mathrm{vol}$, with Freund's complete adjuvant; for the subsequent immunizations HLE was mixed 1:1 with incomplete Freund's adjuvant or PBS. The antiserum when tested by immunodiffusion against HLE and against crude neutrophil granule extracts showed one smoothly fused precipitin line.

Immunodiffusion. The center well of agar-coated slides was filled with whole HLE antiserum. Surrounding wells received either $5 \mu \mathrm{g}$ HLE $(1 \mathrm{mg} / \mathrm{ml}$; wt/vol), or U-937 cell fractions from Trasylol-Sepharose that had been concentrated by positive pressure filtration (PM-10 membranes, Amicon Corp., Scientific Sys. Div. Lexington, Mass.) to have elastolytic activity equivalent to $1 \mathrm{mg} \mathrm{HLE} / \mathrm{ml}$. Monocyte cell extract could not be tested because sufficiently high concentrations of elastase activity were not available.

Enzyme-linked immunoabsorbent assay (ELISA) for $H L E$. Immunologic cross-reactivity between the various elastases was studied with a solid-phase competitive inhibition immunoassay using ELISA technique (36). To prevent interactions between proteinase inhibitors in the antiserum and elastases, all test materials were pre-exposed to $0.005 \mathrm{M}$ PMSF and loss of elastolytic activity was confirmed. 
The procedure was as follows: $2 \mu \mathrm{g}$ PMSF-inactivated HLE in $200 \mu \mathrm{l}$ of borate-buffered saline, $\mathrm{pH} \mathrm{8.2,} \mathrm{was} \mathrm{placed}$ in wells of a polyvinyl chloride microtiter plate ( $\mathrm{V}$ Microtiter, Dynatech Laboratories Inc., Alexandria, Va.). The plate was incubated overnight at $4^{\circ} \mathrm{C}$ and then flicked to empty the wells. Ovalbumin (Sigma Chemical Co.), $200 \mu \mathrm{l}$ of a $1 \%$ solution, wt/vol, in PBS containing $0.1 \%$ Tween, was added to each well and the plates were held at room temperature for $2 \mathrm{~h}$. After the plates were flicked, the wells were washed three times with PBS-Tween, $100 \mu \mathrm{l}$ of mixtures of 1:1,000 dilution of HLE antiserum alone, or HLE antiserum that had been preincubated for $18 \mathrm{~h}$ at $4^{\circ} \mathrm{C}$ with PMSFinactivated elastases, were added to the wells. After overnight incubation at $4^{\circ} \mathrm{C}$, the wells were aspirated and washed three times with PBS-Tween. Antibody-phosphatase conjugate (100 $\mu$ l of a 1:100 dilution of stock solution) was then added to each well. The stock solution of the antibody-phosphatase conjugate, $1 \mathrm{mg}$ protein $/ \mathrm{ml}$, contained alkaline phosphatase (type VII, Sigma Chemical Co.) which had been conjugated with $0.2 \%$ diglutaraldehyde, vol/vol, to affinity purified goat anti-mouse IgG (Gateway Immunosera, St. Louis, Mo.). After 90 -min incubation at $37^{\circ} \mathrm{C}$ the wells were washed three times with PBS-Tween. To each well was added $100 \mu \mathrm{l}$ of freshly prepared solution of $p$-nitrophenyl phosphate, (phosphatase tablets No. 104, Sigma Chemical Co.). The substrate solution contained six tablets per $50 \mathrm{ml}$ of buffer prepared as follows: $48 \mathrm{ml}$ diethanolamine, $400 \mathrm{ml}$ water, $24.5 \mathrm{mg} \mathrm{MgCl} \cdot 6 \mathrm{H}_{2} \mathrm{O}$, in a total volume of $500 \mathrm{ml}$ of water at $\mathrm{pH} 9.8$. After addition of the substrate, the plate was incubated at room temperature for $30 \mathrm{~min}$ and then scored by eye for the presence of yellow color in the wells. The assay was stopped after appearance of sufficient colored reaction product by addition of $50 \mu \mathrm{l}$ of $3 \mathrm{~N} \mathrm{NaOH}$. Reaction product was never seen with preimmune serum, whereas faint color was observed with the immune serum at 1:10,000 dilution.

To quantify HLE-immunoreactive activity in U-937 cell and monocyte extracts, a competitive-binding ELISA was used. This assay tested the ability of PMSF-inactivated elastases to bind anti-HLE antibody in an 18-h preincubation, thus preventing binding of the antibody to the HLE adherent to the microtiter plate wells. The elastases tested were HLE (1-200 ng), U-937 cell elastase, monocyte elastase, and porcine pancreatic elastase (Elastin Products, St. Louis, Mo.). The latter does not crossreact with anti-HLE antibody. For these assays, the intensity of the color developed was quantified spectrophotometrically at $410 \mathrm{~nm}$.

Cytochemistry. In an effort to localize elastaselike activity in U-937 cells, $2.5 \times 10^{5}$ cells were pelleted onto albumincoated glass slides, using a cytocentrifuge, then fixed for $\mathbf{0 . 5}$ $\mathrm{h}$ in $2 \%$ (vol/vol) glutaraldehyde in $0.1 \mathrm{M}$ cacodylate buffer, pH 7.4, containing $1 \%$ (wt/vol) sucrose. The slides were washed with cacodylate buffered with $1 \%$ sucrose by three 1-h changes or by a single overnight exposure. The cells were then infiltrated with $10 \%$ glycerol in cacodylate buffer (vol/ vol) and frozen briefly on the stage of a $\mathrm{CO}_{2}$-cooled freezing microtome to increase their permeability. After a brief rinse in cacodylate-buffered sucrose the cells were transferred to Tris-maleate buffer, $\mathrm{pH} 7.6$, incubated for $1.5 \mathrm{~h}$ with the esterase substrate $N$-t-butoxycarbonyl-L-alanine- $p$-nitrothiophenyl ester (Boc-Ala-SNp, obtained from Dr. Herbert M. Kagan, Boston University School of Medicine, Boston, Mass.) and sodium auriothiosulfate, as described by Clark et al. (37). Control slides were incubated with CMK for $1 \mathrm{~h}$, and then incubation was continued for $1.5 \mathrm{~h}$ in complete substrate. Additional controls had either the ester substrate or the sodium aurothiosulfate omitted. At the end of the period of incubation, the cells were fixed in $1 \% \mathrm{OsO}_{4}$ in $0.1 \mathrm{M}$ cac- odylate buffer, pH 7.4, dehydrated with acetone, and embedded in epoxy resin. BEEM capsules filled with resin were inverted, placed over the cells on the slide and polymerized at $60^{\circ} \mathrm{C}$. The capsules were cleaved from the slides by immersion in liquid nitrogen. Thin sections cut with a diamond knife were collected on copper grids and examined in a JEOL $100 \mathrm{C}$ electron microscope either without additional staining or after staining with saturated uranyl acetate in $50 \%$ ethanol. Reaction product was visible as an electron opaque precipitate of gold-p-nitrothiophenolate.

\section{RESULTS}

Elastase activity in U-937 cells, monocytes, and neutrophils. Extracts of U-937 cells solubilized $\sim 24$ $\mu \mathrm{g}$ of elastin $/ 10^{6}$ cells in $24 \mathrm{~h}$ at $37^{\circ} \mathrm{C}$. The activity was substantially lower if the cell extract was prepared without freeze-thawing, despite complete cell disruption by sonication. The activity was stable for long periods at $-70^{\circ} \mathrm{C}$; indeed, the activity appeared somewhat enhanced after frozen storage. Extracts from monocytes had similar elastase activity per cell as the U-937 cell extracts; neutrophils had $\sim 30$-fold greater elastase activity per cell than either U-937 cells or monocytes. U-937 elastase activity showed a pH optimum at 8.0 .

Less than $10 \%$ of the U-937 and monocyte cell extract proteinase activities against ${ }^{125}$ I-labeled fibronectin remained after incubation with CMK indicating that elastolytic proteinase(s) account for most of the neutral proteinase activity associated with these cells.

Comparison between the catalytic properties of $U$ 937 elastase activity, monocyte elastase activity, and P388D1 elastase activity. The elastase activities associated with U-937 cells and monocytes were similar and different from P388D1 cell elastase activity in studies with proteinase inhibitors (Table I). PMSF, CMK, and alpha-1-proteinase inhibitor strongly inhibited U-937 and monocyte elastase activities, but had minimal or no effect against elastase activity released from P388D1 cells. SBTI was also an effective inhibitor. In contrast, EDTA abolished P388D1 elastase activity, but had no effect against the elastase activity associated with either U-937 cells or monocytes. It was notable that $5 \%$ ( $\mathrm{vol} / \mathrm{vol})$ dimethylformamide, used to solubilize PMSF, inhibited P388D1 elastase activity but had no effect against U-937 or monocyte elastase activities, a finding that highlights the need for testing the effects of all solvents.

The elastase activities associated with U-937 and P388D1 cells were influenced differently by $\mathrm{NaCl}$. As has been described for HLE, increasing the $\mathrm{NaCl}$ concentration in the assay test buffer markedly increased the elastase activity of U-937 cell extracts (Fig. 1). $\mathrm{NaCl}$ had no effect on the elastase activity in P388D1 cell conditioned medium. $\mathrm{CaCl}_{2}$, even in trace amounts (as little as $1 \mu \mathrm{M}$ ), however, enhanced the elastase activity associated with both cell types. The effect of 
TABLE I

The Effects of Proteinase Inhibitors upon the Elastase Activity of U-937 Cell Extract, Monocyte Cell Extract, and P388D1 Cell-conditioned Medium

\begin{tabular}{lccc}
\hline & \multicolumn{3}{c}{ Percentage of control } \\
\cline { 2 - 4 } \multicolumn{1}{c}{ Inhibitor (concentration) } & $\mathrm{U}-937$ & Monocyte & P388D \\
\hline PMSF $(5 \mathrm{mM})$ & 0 & 3 & $100^{\circ}$ \\
CMK (0.6 mM) & 1 & 0 & 100 \\
Alpha-1-proteinase inhibitor & & & \\
$\quad(0.2 \mathrm{mg} / \mathrm{ml})$ & 0 & 2 & 63 \\
SBTI (1 mg/ml) & 15 & 16 & 59 \\
EDTA $(5 \mathrm{mM})$ & 97 & 92 & 5 \\
\hline
\end{tabular}

Results are means of a minimum of two separate studies done in duplicate. Elastase activities of the controls were similar, sufficient to release $3,000-17,000 \mathrm{cpm}$ from ${ }^{14} \mathrm{C}$-labeled elastin.

- The solvent dimethylformamide alone reduced activity to $62 \%$ of control; addition of PMSF had no further effect.

calcium upon P388Dl elastase activity occurred irrespective of the presence of $\mathrm{NaCl}$, indicating that $\mathrm{NaCl}$ does not inhibit P388Dl elastase activity.

Both U-937 cell and monocyte extracts readily hydrolyzed SLAPN and MSAPN. Inhibition of the activity against elastin with CMK also abolished the activity against SLAPN, strongly suggesting that the elastase activity in U-937 cell and monocyte extracts was also responsible for the activity against SLAPN. In contrast, P388Dl cell-conditioned medium, which had elastase activity, showed no activity against SLAPN or MSAPN.

Release of elastase activity by U-937 and P388D1 cells in culture. Compared to the intracellular content of elastase activity, U-937 cells released minimal elastase activity into culture medium (Fig. 2). Failure to find elastase activity in the medium was not a result of poor cell viability in serumless medium during the

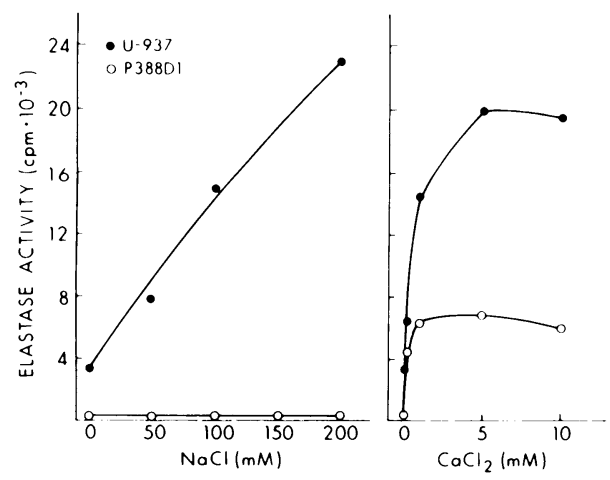

Figure 1 The influence of $\mathrm{NaCl}$ (left) and $\mathrm{CaCl}_{2}$ (right) upon the elastase activity in U-937 cell extracts and P388D 1 cell-conditioned medium. 24-h incubation, however, since the cells secreted lysozyme, excluded trypan blue, and the medium contained only traces of lactate dehydrogenase, comparable to amounts found with cells cultured in the presence of serum (after correction for the lactate dehydrogenase in the serum added to the medium). In marked distinction, elastase activity was readily detected in relatively large amounts in medium conditioned by P388Dl cells, while extracts of these cells contained only $3-5 \%$ of the total cell-associated elastase activity. Thus, U-937 and P388D1 cells differ markedly in the partition of elastase between the cell and the culture medium.

Chromatographic observations. Fig. 3 depicts the chromatographic properties of U-937 cell extract elastase activity on Trasylol-Sepharose. Using a two buffer elution system, two peaks of activity were observed, one that did not adhere to the resin at $\mathrm{pH} 8$, and one that adhered at $\mathrm{pH} 8$ but could be eluted at $\mathrm{pH} 5.5$. No further elastase was eluted by washing the column with buffer of lower $\mathrm{pH}$. The elastolytic activity in the second peak relative to total protein was enriched $\sim 200$-fold compared to the starting material. On separate reapplication of each peak, the peaks showed the same retention pattern, indicating that the first peak did not result from overloading the column.

Application of U-937 cell extract to CM-Sephadex (Fig. 4) demonstrated that a large fraction of the elas-

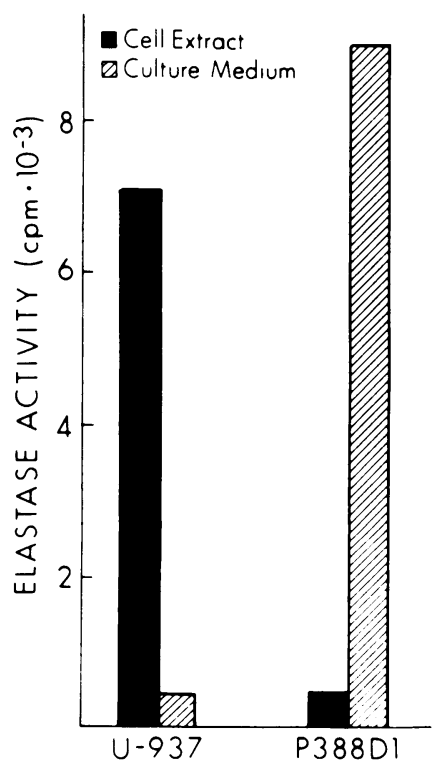

Figure 2 Comparison of elastase activity in cell extracts and cell-conditioned medium. Cells were cultured for $24 \mathrm{~h}$ in serumless medium at a density of $2 \times 10^{6}$ cells $\mathrm{ml} .200$ $\mu \mathrm{l}$ of cell extract or unconcentrated medium was used for assay of elastase activity. Results shown are the mean of duplicate observations. 


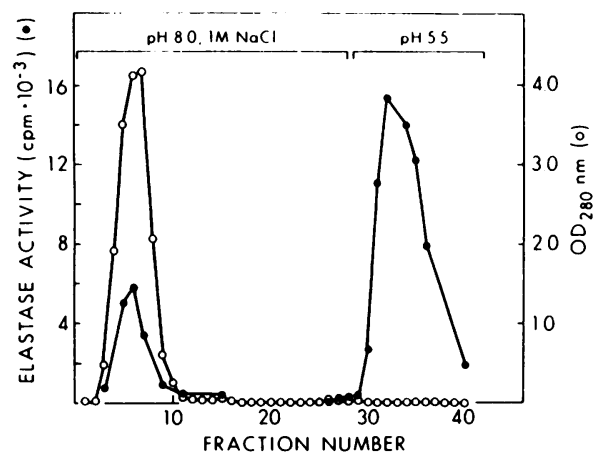

FIGURE 3 The elastase activity of U-937 cell extract fractionated by Trasylol-Sepharose affinity chromatography.

tase activity did not bind to the resin; the remaining activity eluted at $\sim 0.4 \mathrm{M} \mathrm{NaCl}$. When peaks containing elastase activity obtained from Trasylol-Sepharose were individually applied to CM-Sephadex in low ionic strength buffer, the peak of activity not binding to the Trasyslol also did not adhere to the CM-Sephadex, whereas the elastase activity retained by Trasysol-Sepharose also bound to CM-Sephadex. Thus, the chromatographic procedure using Trasylol-Sepharose resolved the elastase activity into two fractions with differing charge.

SDS-polyacrylamide gel electrophoresis of $\left[{ }^{3} \mathrm{H}\right] D F P$ labeled proteinases. Autofluorograms of reduced whole cell extracts of U-937 cells and monocytes subjected to SDS-polyacrylamide gel after exposure to $\left[{ }^{3} \mathrm{H}\right] \mathrm{DFP}$ demonstrated similar patterns. Both cell extracts showed two prominent bands of $\left[{ }^{3} \mathrm{H}\right] \mathrm{DFP}$ localization corresponding to $\sim 30,000 \mathrm{~mol}$ wt and 60,000 mol wt, and a faint zone of activity at $\sim 80,000 \mathrm{~mol}$ wt. (Fig. 5). The material from U-937 cells that adhered to both Trasylol-Sepharose and to CM-Sephadex showed only a single band of radiolabel, corresponding to the migration of HLE, $\sim 30,000 \mathrm{~mol}$ wt.

Immunologic observations. Elastase-containing

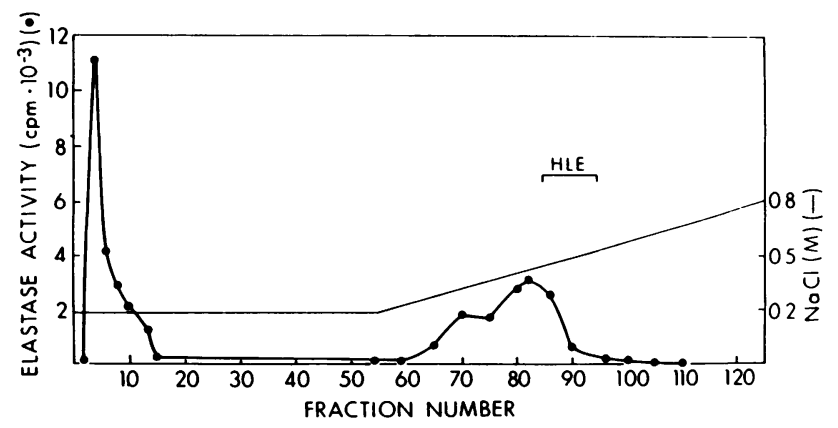

Figure 4 Chromatography of U-9.37 cell extract elastase activity fractionated by CM-Sephadex chromatography.

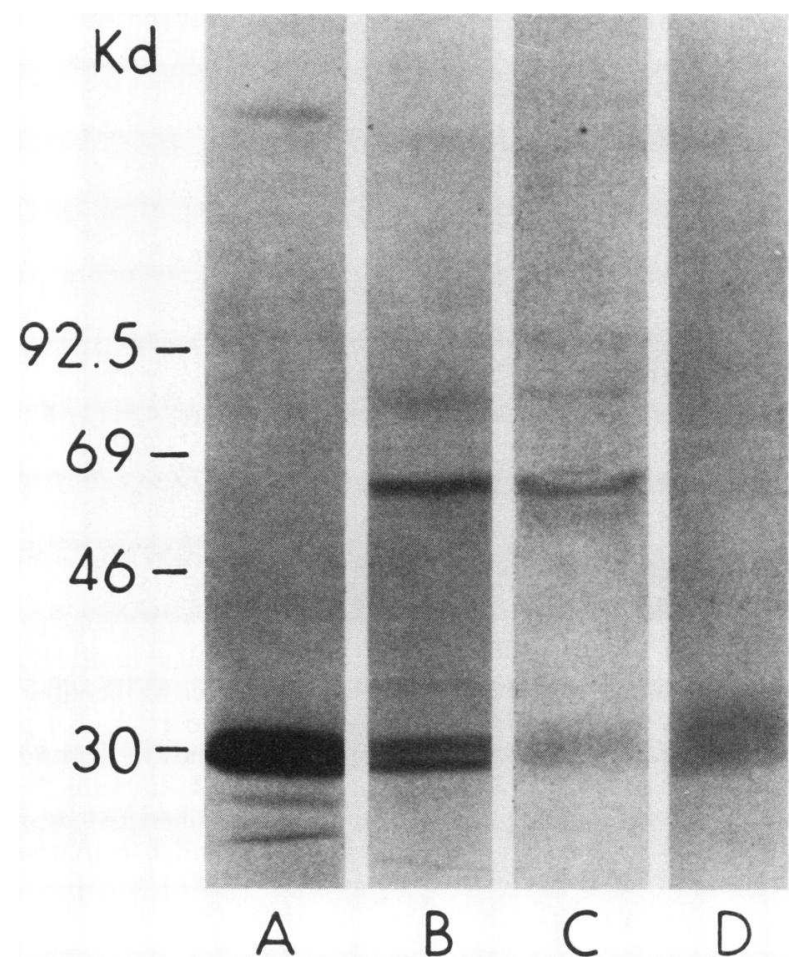

Figure 5 Autofluorograms ([ $\left.\left.{ }^{3} \mathrm{H}\right] \mathrm{DFP}\right)$ of SDS-polyacrylamide gel electrophoresis preparations (A) HLE; (B) U-937 cell extract; (C) monocyte extract; (D) U-937 cell extract adherent to Trasylol-Sepharose (Methods). The standards are phosphorylase B, bovine serum albumin, ovalbumin, and carbonic anhydrase.

fractions from U-937 cells demonstrated lines of identity with HLE in immunodiffusion against anti-HLE antiserum (Fig. 6). Equivalent amounts of elastolytic activities of HLE and the U-937 fraction that adhered to Trasylol-Sepharose gave similarly heavy precipitin bands. U-937-derived material that did not adhere to Trasylol showed less immunoprecititation, but its immunoprecipitin band also formed a line of identity with the HLE precipitin bands.

The competitive binding ELISA assay indicated an excellent correlation between HLE immunoreactivity and elastase activity among $\mathrm{U}-937$ cell-derived material, monocyte cell extracts, and HLE (Fig. 7). Pancreatic elastase, however, even at high concentration, showed little immunoreactivity in the assay.

Cytochemistry. The capacity of U-937 cell extracts to hydrolyse SLAPN was consistent with findings using Boc-Ala-SNp as a substrate for cytochemical studies. U-937 cells exposed to Boc-Ala-SNp revealed electron dense reaction product in the endoplasmic reticulum and Golgi cisternae, in occasional small $(0.1-0.2-\mu \mathrm{m})$ vesicles throughout the cytoplasm, and at the edges of lipid droplets (Fig. 8, left). In cells preincubated 


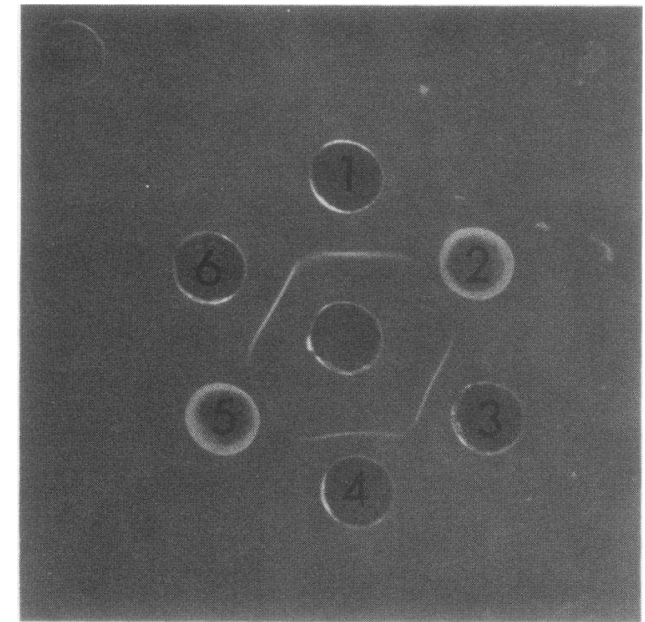

FIGURE 6 Immunodiffusion of U-937 fractions and HLE against rabbit anti-HLE antiserum. The center well contains antiserum and the surrounding wells contain HLE, $5.4 \mu \mathrm{g}$ and $1.14 \mu \mathrm{g}$ in wells 1 and 3, respectively, and the first and second peak from Trasylol-Sepharose (Fig. 4) in wells 2, 5 and 4,6 , respectively. Wells 2 and 4 contained $5.4 \mu \mathrm{g}$ of HLE-like elastolytic activity and wells 5 and 6 contained $1.14 \mu \mathrm{g}$ of HLE-like elastolytic activity.

with CMK, reaction product was visible only in vesicles and lipid droplets, suggesting that most of the heavy metal deposition seen in cells not exposed to CMK was due to esterase activity (Fig. 8, right). The location of the reaction product in U-937 cells was quite similar to the localization observed by Clark et al. (36) in virtually all blood cells. Like those studies, in which neutrophils did not show uniform intense reaction product in the granules despite the large quantity of HLE present, U-937 cells did not demonstrate prominent granule staining.

\section{DISCUSSION}

U-937 cells and monocytes have readily detectable elastase activity that comprises a major portion of the total neutral proteinase activity associated with extracts of the cells. The catalytic properties of the elastases in U-937 cells and monocytes showed similarities $(a)$ in both cells the elastases were serine proteinases; and $(b)$ the inhibition profiles, and the activities of the elastases against synthetic substrates were similar.

The demonstration of similar elastases in U-937 cells and monocytes is important because U-937 cells grow in culture as a continuous line without contact with other cells (especially neutrophils), so that the cell-associated elastase is clearly a product of the cells rather than an elastase accumulated from external sources. This observation argues against the possibility that monocytes harvested from peripheral blood contain only elastase(s) derived from external sources, inter- nalized either as complexes with alpha-2-macroglobulin or in the case of HLE, possibly as free enzyme (14).

Prepared U-937 whole cell extracts prepared by freeze-thawing solubilize roughly $24 \mu \mathrm{g}$ elastin $/ 10^{6}$ cells in $24 \mathrm{~h}, \sim 3 \%$ of that achieved with freeze-thawed extracts of neutrophils. This activity, however, represents only the lower limit of the amount of enzyme present, because cytoplasmic inhibitors may have reduced the amount of observable activity, or other cell components may have provided alternative substrates for the enzyme in elastase assays. Indeed, during chromatographic purification, the cumulative amounts of elastase activity recovered from U-937 cells were always substantially greater than the apparent activity of the starting cell extract. This finding, similar to that of Banda and Werb (7) in purifications of mouse macrophage elastase, suggests that U-937 cells have endogenous elastase inhibitory activity. The apparent cell elastase activity may thus vary widely depending upon the purity of the preparation being assayed.

U-937 elastase activity is found almost exclusively in cell extracts; medium conditioned by the cells contained little activity. Failure of the cells to secrete elastase activity should not be attributed to the fact that the U-937 cells are transformed, since cells of the P388D1 murine macrophage line (as reported previously and confirmed here) do secrete elastase (15). Ragsdale and Arend (8) found relatively small amounts

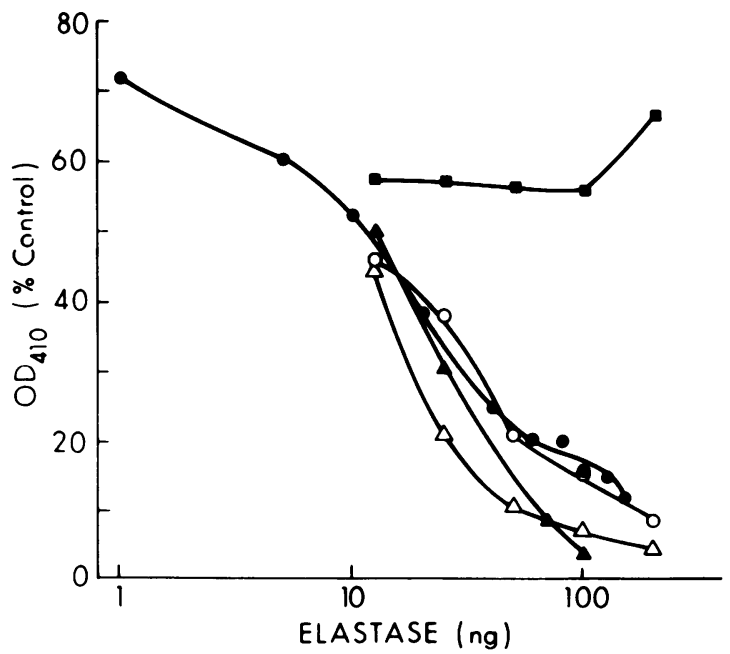

Figure 7 Competitive inhibition ELISA of HLE - monocyte cell extract $O$, the first $\Delta$ and second $\Delta$ peaks of elastase activity recovered by Trasylol-Sepharose chromatography of U-937 cell extract (Fig. 4), and porcine pancreatic elastase - (see text for details). The quantities of U-937 cell and monocyte elastases are based on equivalents of HLE activity as determined by standardizing the cell extracts against HLE using ${ }^{14} \mathrm{C}$-labeled elastin. 

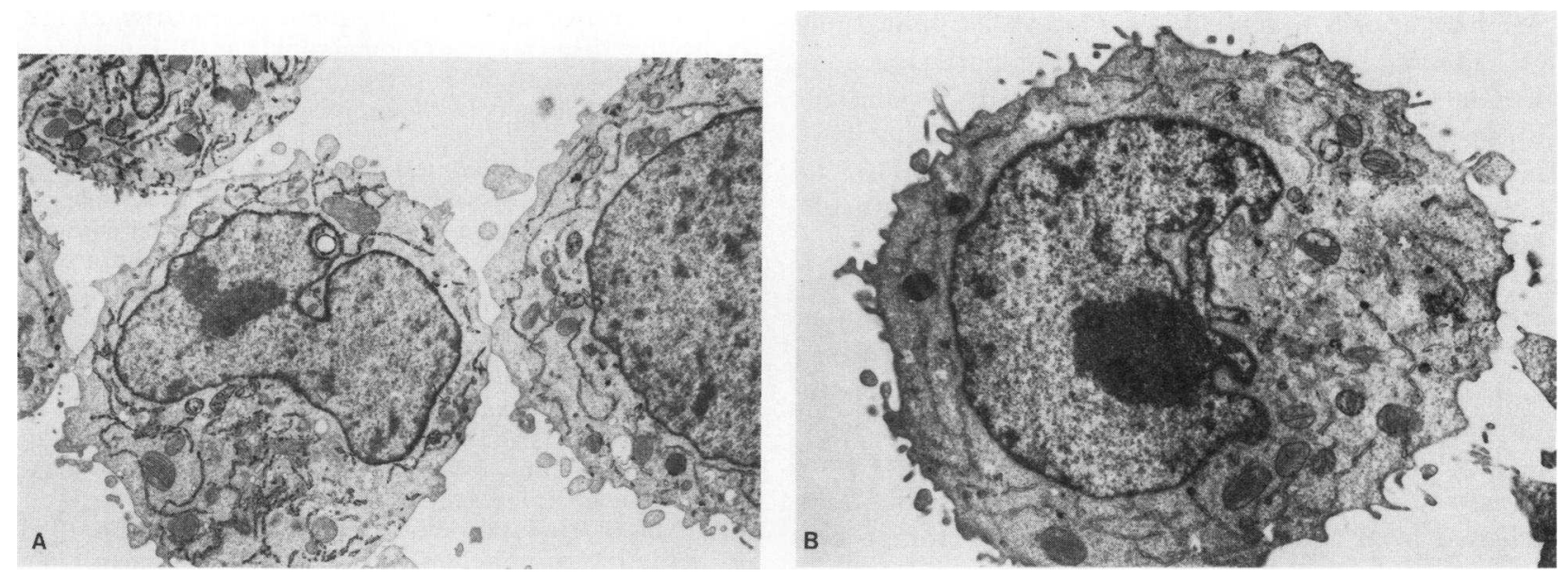

Figure 8 Electron micrographs of U-937 cells exposed to Boc-Ala-SNp and gold ions. A, electron dense reaction product is prominent in the Golgi and endoplasmic reticulum, $\times 7300$; B; a U-937 cell exposed to a specific elastase inhibitor, CMK, before Boc-Ala-SNp and gold ions, shows deposition of heavy metal restricted to vesicles and lipid droplets, $\times 8300$.

of plasminogen-independent proteinase activity released by unstimulated monocytes. The lack of elastase secretion by U-937 cells may also reflect a characteristic of normal human alveolar macrophages, which appear to secrete little elastase activity (38-41).

The elastase activity associated with U-937 cells and monocytes is due to one or more serine proteinases that share with HLE the properties of hydrolysing SLAPN and MSAPN and of being inhibited by PMSF, SBTI, CMK, and alpha-1-proteinase inhibitor $(28,29,42)$. Thus, elastase activities associated with U-937 cells and monocytes differ from murine macrophage elastase, whether derived from normal mouse macrophages or from the P388D1 line of murine macrophagelike cells. These macrophage elastases are calcium dependent, inhibited by EDTA, unaffected by inhibitors of serine proteinases, and without activity against synthetic elastase substrates such as SLAPN and MSAPN $(7,43$, 44). The catalytic features of U-937 elastase are noteworthy for at least two reasons: $(a)$ they match elastase activity of human monocytes described in several reports and $(b)$ they provide further evidence that serine proteases with elastase activity are associated with human mononuclear phagocytes $(8,9)$.

The fraction of U-937 elastase activity that adheres to Trasylol-Sepharose and CM-Sephadex appears similar or identical to HLE. Preliminary studies done in collaboration with Dr. James C. Powers show that U937 elastolytic activity and HLE have similar values for $K_{m}$ and $V_{\max }$ against MSAPN and show similar profiles of inhibition by a series of chloromethylketones (45).

U-937 cells and monocytes contain immunoreactive material that strongly cross-reacts with HLE. That HLE or a closely related material is a normal product of monocytes has support from the findings of Pryzwansky et al. (46) who observed that some human monocytes exhibit immunofluorescence with antiserum to HLE shortly after being put into culture.

Both U-937 cells and monocytes appear to have a multiplicity of elastases. Lavie et al. (9) found that monocytes show more than one form of elastase in SDS-polyacrylamide gel electrophoresis autofluorograms using radiolabeled chloromethylketone elastase inhibitors. In that study, a 58,000-mol wt product was the main elastase associated with the cell surface, while 25-35K and 50-60K elastases were dominant in cell lysates, similar to the present work with U-937 cell lysates.

The precise relationship of U-937 elastases to elastases associated with normal monocytes will remain unsettled until the monocyte and U-937 elastases are purified. The fact that monocytes undergo changes in their enzyme content and profile during maturation in vitro (10), and the stage of normal monocyte development to which U-937 cells correspond is unknown, suggests monocytes and U-937 cells may have some differences between their elastases relating to stages of cell maturation. In this regard it is noteworthy that, unlike monocytes, elastolytic activity is not readily detectable in extracts of mature alveolar macrophages $(39,41)$ indicating that maturational changes in mononuclear phagocyte elastase occur during the transition from monocytes to macrophages.

As prototypes of normal monocytes and macrophages, cells of continuous cell lines, such as the U- 
937 line, appear to have diverse research applications (16). They may prove convenient for purifying constituents of normal macrophages. Indeed, the similarities between P388Dl elastase and the elastase of normal murine macrophages led Werb et al. (15) to propose that P388Dl cells could be a source of murine macrophage elastase.

The finding that monocytes contain serine proteinase activity against elastin has interesting implications for the hypothesis that imbalance between proteinases and proteinase inhibitors plays a pathogenetic role in the development of emphysema. Several lines of compelling evidence point to inactivation of alphal-proteinase inhibitor by oxidants in cigarette smoke and released from neutrophils as important factors in upsetting the normal proteinase-proteinase inhibitor relationship in favor of proteolysis $(13,47-50)$. Until now the elastase implicated in this scenario has been HLE, because of its susceptibility to inhibition by alpha-1proteinase inhibitor. The present work showing that monocytes, the precursors of macrophages, also contain elastase activity that is inhibited by alpha-1-proteinase inhibitor implicates this cell type as another possible source of elastase activity that can be unleashed when circulating proteinase inhibitors are present in insufficient quantity or are rendered inactive.

\section{ACKNOWLEDGMENTS}

The authors appreciate the assistance of Wayne Engleman in preparation of the electron micrographs, the advice of Dr. George D. Wilner and Dr. George J. Broze concerning ELISA procedures and monocyte purification, and the assistance of Dr. James C. Powers with elastase inhibitors.

This work was supported by U. S. Public Health Service grants HL16118 and HL24265, and by the American Lung Association-Eastern Mo.

\section{REFERENCES}

1. Janoff, A. 1978. Granulocyte elastase: role in arthritis and in pulmonary emphysema. In Neutral Proteases of Human Polymorphonuclear Leukocytes. K. Havemann and A. Janoff, editors. Urban \& Schwarzenberg, Inc., Baltimore-Munich. 390-417.

2. Janoff, A., B. Sloan, G. Weinbaum, V. Damiano, R. A. Sandhaus, J. Elias, and P. Kimbel. 1977. Experimental emphysema induced with purified human neutrophil elastase: tissue localization of the instilled protease. Am. Rev. Respir. Dis. 115: 461-478.

3. Senior, R. M., H. Tegner, C. Kuhn, K. Ohlsson, B. C. Starcher, and J. A. Pierce. 1977. The induction of pulmonary emphysema with leukocyte elastase. Am. Rev. Respir. Dis. 116: 469-475.

4. Werb, Z., M. J. Banda, and P. A. Jones. 1980. Degradation of connective tissue matrices by macrophages: $I$. Proteolysis of elastin, glycoproteins, and collagen by proteinases isolated from macrophages. J. Exp. Med. 152: 1340-1357.
5. Jones, P. A., and Z. Werb. 1980. Degradation of connective tissue matrices by macrophages: II. Influence of matrix composition on proteolysis of glycoproteins, elastin, and collagen by macrophages in culture. J. Exp. Med. 152: 1527-1536.

6. Werb, Z., D. F. Bainton, and P. A. Jones. 1980. Degradation of connective tissue matrices by macrophages: III. Morphological and biochemical studies on extracellular, pericellular, and intracellular events in matrix proteolysis by macrophages in culture. J. Exp. Med. 152: 1537-1553.

7. Banda, M. J., and Z. Werb. 1981. Mouse macrophage elastase: purification and characterization as a metalloproteinase. Biochem. J. 193: 589-605.

8. Ragsdale, C. G., and W. P. Arend. 1979. Neutral protease secretion by human monocytes: effect of surface-bound immune complexes. J. Exp. Med. 149: 954-968.

9. Lavie, G., D. Zucker-Franklin, and E. C. Franklin. 1980. Elastase-type proteases on the surface of human blood monocytes: possible role in amyloid formation. J. Immunol. 125: 175-180.

10. Musson, R. A., H. Shafran, and P. M. Henson. 1980. Intracellular levels and stimulated release of lysosomal enzymes from human peripheral blood monocytes and monocyte-derived macrophages. J. Reticuloendothel. Soc. 28: 249-264.

11. Newman, S. L., R. A. Musson, and P. M. Henson. 1980. Development of functional complement receptors during 'in vitro' maturation of human monocytes into macrophages. J. Immunol. 125: 2236-2244.

12. Zuckerman, S. H., S. K. Ackerman, and S. D. Douglas. 1979. Long-term human peripheral blood monocyte cultures: establishment, metabolism, and morphology of primary human monocyte-macrophage cell cultures. Immunology 38: 401-411.

13. Carp, H., and A. Janoff. 1979. In vitro suppression of serum elastase-inhibitory capacity by reactive oxygen species generated by phagocytosing polymorphonuclear leukocytes. J. Clin. Invest. 63: 793-797.

14. Campbell, E. J., R. R. White, R. M. Senior, R. J. Rodriguez, and C. Kuhn. 1979. Receptor-mediated binding and internalization of leukocyte elastase by alveolar macrophages in vitro. J. Clin. Invest. 64: 824-833.

15. Werb, Z., R. Foley, and A. Munck. 1978. Glucocorticoid receptors and glucocorticoid-sensitive secretion of neutral proteinases in a macrophage line. J. Immunol. 121: 115-121.

16. Ralph, P. 1981. Established cell lines as a source of functional macrophages. In Manual of Macrophage Methodology: Collection, Characterization, and Function. H. B. Herscowitz, H. T. Holden, J. A. Bellanti, and A. Ghaffar, editors. Marcel Dekker, Inc., New York. 5059.

17. Sundstrom, C., and K. Nilsson. 1976. Establishment and characterization of a human histiocytic lymphoma cell line (U-937). Int. J. Cancer. 17: 565-577.

18. Ralph, P., M. A. S. Moore, and K. Nilsson. 1976. Lysozyme synthesis by established human and murine histiocytic and lymphoma cell lines. J. Exp. Med. 143: 1528-1533.

19. Bodel, P., P. Ralph, K. Wenc, and J. C. Long. 1980. Endogenous pyrogen production by Hodgkin's disease and human histiocytic lymphoma cell lines in vitro. $J$. Clin. Invest. 65: 514-518.

20. Pike, M. C., D. G. Fischer, H. S. Koren, and R. Snyderman. 1980. Development of specific receptors for $N$ formylated chemotactic peptides in a human monocyte 
cell line stimulated with lymphokines. J. Exp. Med. 152: 31-40.

21. Fischer, D. G., M. C. Pike, H. S. Koren, and R. Snyderman. 1980. Chemotactically responsive and nonresponsive forms of a continuous human monocyte cell line. J. Immunol. 125: 463-465.

22. Wing, E. J., H. S. Koren, D. G. Fischer, and V. Kelley. 1981. Stimulation of a human macrophage-like cell line (U-937) to inhibit multiplication of an intracellular pathogen. J. Reticuloendothel. Soc. 29: 321-328.

23. Böyum, A. 1968. Isolation of mononuclear cells and granulocytes from human blood: isolation of mononuclear cells by one centrifugation, and of granulocytes by combining centrifugation and sedimentation at $1 \mathrm{~g}$. Scand. J. Clin. Lab. Invest. 21(Suppl. 97): 77-89.

24. Weiner, R. S., and V. O. Shah. 1980. Purification of human monocytes: isolation and collection of large numbers of peripheral blood monocytes. J. Immunol. Methods. 36: 89-97.

25. Kalb, V. F., Jr. and R. W. Bernlohr. 1977. A new spectrophotometric assay for protein in cell extracts. Anal. Biochem. 82: 362-371.

26. Bielefeld, D. R., R. M. Senior, and S. Y. Yu. 1975. A new method for determination of elastolytic activity using ${ }^{14} \mathrm{C}$-labeled elastin and its application to leukocytic elastase. Biochem. Biophys. Res. Commun. 67: 1553-1559.

27. Baugh, R. J., and J. Travis. 1976. Human leukocyte granule elastase: rapid isolation and characterization. Biochemistry. 15: 836-841.

28. Bieth, J., B. Spiess, and C. G. Wermuth. 1974. The synthesis and analytical use of a highly sensitive and convenient substrate of elastase. Biochem. Med. 11: 350357.

29. Castillo, M. J., K. Nakajima, M. Zimmerman, and J. C. Powers. 1979. Sensitive substrates for human leukocyte and porcine pancreatic elastase: a study of the merits of various chromophoric and fluorogenic leaving groups in assays for serine proteases. Anal. Biochem. 99: 53-64.

30. Wroblewski, F., and J. S. LaDue. 1955. Lactic dehydrogenase activity in blood. Proc. Soc. Exp. Biol. Med. 90: $210-213$

31. Gordon, S., J. Todd, and Z. A. Cohn. 1974. In vitro synthesis and secretion of lysozyme by mononuclear phagocytes. J. Exp. Med. 139: 1228-1248.

32. Varani, J., K. Johnson, and J. Kaplan. 1980. Development of a solid-phase assay for measurement of proteolytic enzyme activity. Anal. Biochem. 107: 377-384.

33. Danø, K., and E. Reich. 1978. Serine enzymes released by cultured neoplastic cells. J. Exp. Med. 147: 745757.23 .

34. Laemmli, U. K. 1970. Cleavage of structural proteins during the assembly of the head of bacteriophage T4. Nature (Lond.). 227: 680-685.

35. McDonald, J. A., and D. G. Kelley, 1980. Degradation of fibronectin by human leukocyte elastase: release of biologically active fragments. J. Biol. Chem. 255: 88488858 .

36. Kearney, J. F., A. Radbruch, B. Liesegang, and K. Rajewsky. 1979. A new mouse myeloma cell line that has lost immunoglobulin expression but permits the construction of antibody-secreting hybrid cell limes. J. Immunol. 123: 1548-1550.

37. Clark, J. M., D. W. Vaughn, B. M. Aiken, and H. M. Kagan. 1980. Elastase-like enzymes in human neutrophils localized by ultra-structural cytochemistry. J. Cell Biol. 84: 102-119.

38. DeCremoux, H., W. Hornebeck, M. C. Jaurand, J. Bignon, and L. Robert. 1978. Partial characterization of an elastase-like enzyme secreted by human and monkey alveolar macrophages. J. Pathol. 125: 171-177.

39. Hinman, L. M., C. A. Stevens, R. A. Matthay, and J. B. L. Gee. 1980. Elastase and lysozyme activities in human alveolar macrophages: effects of cigarette smoking. Am. Rev. Respir. Dis. 121: 263-271.

40. Green, M. R., J. S. Lin, L. B. Berman, M. M. Osman, J. M. Cerretta, I. Mandl, and G. M. Turino. 1979. Elastolytic activity of alveolar macrophages in normal dogs and human subjects. J. Lab. Clin. Med. 94: 549-562.

41. Rodriguez, R. J., R. R. White, R. M. Senior, and E. A. Levine. 1977. Elastase release from human alveolar macrophages: comparison between smokers and non-smokers. Science (Wash. D. C.). 198: 313-314.

42. Janoff, A. 1972. Human granulocyte elastase: further delineation of its role in connective tissue damage. Am. J. Path. 68: 579-591.

43. Werb, Z., and S. Gordon. 1975. Elastase secretion by stimulated macrophages. Characterization and regulation. J. Exp. Med. 142: 361-377.

44. White, R., H. S. Lin and C. Kuhn, III. 1977. Elastase secretion by peritoneal exudative and alveolar macrophages. J. Exp. Med. 146: 802-808.

45. Powers, J. C., B. F. Gupton, A. D. Harley, N. Nishino, and R. J. Whitley. 1977. Specificity of porcine pancreatic elastase, human leukocyte elastase, and cathepsin G: inhibition with peptide chloromethyl ketones. Biochim. Biophys. Acta. 485: 156-166.

46. Pryzwansky, K. B., L. E. Martin, and J. K. Spitznagel. 1978. Immunocytochemical localization of myeloperoxidase, lactoferrin, lysozyme, and neutral proteases in human monocytes and neutrophilic granulocytes. J. Reticuloendothel. Soc. 24: 295-310.

47. Gadek, J. E., G. A. Fells, and R. G. Crystal. 1979. Cigarette smoking induces functional antiprotease deficiency in the lower respiratory tract of humans. Science (Wash. D. C.). 206: 1315-1316.

48. Janoff, A., H. Carp, D. K. Lee, and R. T. Drew. 1979. Cigarette smoke inhalation decreases $\alpha_{1}$-antitrypsin activity in rat lung. Science (Wash. D. C.). 206: 13131314.48 .

49. Matheson, N. R., P. S. Wong, and J. Travis. 1979. Enzymatic inactivation of human alpha-1-proteinase inhibitor by neutrophil myeloperoxidase. Biochem. Biophys. Res. Commun. 88: 402-409.

50. Wong, P. S., and J. Travis. 1980. Isolation and properties of oxidized alpha-1-proteinase inhibitor from human rheumatoid synovial fluid. Biochem. Biophys. Res. Commun. 96: 1449-1454. 